\title{
Assessment of Consultations for an Industrial Distribution Writing Intensive Course
}

\section{Prof. Pauline Melgoza, Texas A\&M University}

Ms. Melgoza is a science and engineering librarian at Texas A and M University. She has 19 of years experience.

\section{Ashlynn Kogut, Texas A\&M University}

Ashlynn Kogut, Assistant Professor, is an Education and Social Sciences Librarian at Texas A and M University Libraries, where she supports researchers in education and the social sciences.

\section{Mr. Michael Ryan Golla, Texas A\&M University}

Mr. Michael R. Golla, Senior Lecturer, Department of Engineering Technology \& Industrial Distribution, College of Engineering, Texas A\&M University.

Education: M.B.A., Texas A\&M University, 2002 B.S., Engineering Tech., Texas A\&M University, 1997

Philanthropic and Endowment Experience: • Strategically developed a new funding model for the ETID department to endow and develop labs to support strategic education curriculum, 2004. • Leveraged professional relationships with Mr. Robert "Bob" Womack, of Womack Machine Supply, Dallas Tx and helped negotiate a $\$ 1.0 \mathrm{M}$ donation for an endowment to support a "hands on" Fluid Power Laboratory, 2007. - Obtained a second gift of $\$ 500 \mathrm{k}$, from personal and professional relationships with DXP Enterprises, to develop the DXP Pump Laboratory to support undergraduate education and the development of a professional development continuing education program to support industry professionals with professional development needs. 2009.

Industry Experience: • Strategic business analyst conducted international and domestic market research in the energy production and manufacturing markets and wrote a strategic business plan to serve the pump package system demand for domestic and international markets. FMC Technologies, Houston, Tx. • Assistant Plant Manager/Welding Engineer, product development and manufacturing engineer in the Fluid Power Industry assessing production inefficiencies to implement new equipment and processes. Texas Hydraulics, Temple Tx. • Welding engineer in assessing inventory and manufacturing equipment, and a manufacturing and product engineer for a Fortune 100 Fluid Power company fulfilling an integral role in developing a robotic welding program to produce hydraulic cylinders. Texas Hydraulics. - Project engineer for the USAF, moving manufacturing facilities from Kelly AFB in San Antonio, Texas to Tinker AFB, in Oklahoma City, Oklahoma. DME, Defense Military Engineers, subcontractor to Lockheed Martin.

Academic Teaching: • Currently subjects, Undergraduate MMET 301 Mechanical Power Transmission MMET 401 Fluid Power Technology

- Professional Development and Continuing Education Short courses Pump 101 Basic Pump Fundamentals Pump 102 Advanced Pump Fundamentals 1 Pump 201 Advanced Pump Fundamentals 2

- Past Subjects, Undergraduate IDIS 303 Mechanical Power Transmission IDIS 403 Fluid Power Technology IDIS 281 Manufacturing Processes ENTC 206 Non-Metallic Materials ENTC 429 Managing People and Projects

Research Interests: Strategic business development, Product innovation, Entrepreneurship in Engineering, Project management, Fluid Power Technologies, Mechanical Power Transmission, Condition based monitoring and Reliability.

BIOGRAPHICAL DATA Name: Michael R. Golla Department: Engineering Technology and Industrial Distribution, Manufacturing and Mechanical Engineering Technology Program Date hired or assigned to department: 2002 Number of years of service to department: 20 Present academic rank and date obtained: Senior Lecturer, 2014 Degrees: M.B.A., Texas A\&M University, College Station, TX, 2002 B.S., 
Engineering, Mechanical Engineering Technology, Texas A\&M University, College Station, TX, 1997 Related teaching and other work experience: Graduate Teaching Assistant, Dr. Clint Bertrand, Engineering Technology and Industrial Distribution, Texas A\&M Univ., College Station, (8/2000 - 5/2002) Business Mgmt Intern - FMC Technologies, Energy Systems, (5/2001 - 8/2001) DME, Project Engineer for USAF, (11/1999 - 2/2000), San Antonio, Tx Assistant Plant Manager / Welding Engineer - Texas Hydraulics, (3/1998 - 10/1999) US Army Corps of Engineers, Lackland AFB, San Antonio, Tx. Engineering Intern, 1996 \& 1997. Active membership in professional and scientific societies: Society of Manufacturing Engineers (SME)

Personal: Married to my "Aggie Sweetheart" for 22 years, we have 3 children, two sons (19) \& (14) and one daughter (11). 


\title{
Assessment of Consultations for an Industrial Distribution Writing Intensive Course
}

\begin{abstract}
Engineering librarians at Texas A\&M University use research consultations to teach engineering student teams information literacy related to the team's professional project. The purpose of this study was to assess the effectiveness of the research consultations with the teams. For four semesters, librarians administered a questionnaire to students about the research consultation after the completion of the professional project. On the last class day, questionnaires were administered in-person both to students who attended a research consultation with a librarian and to students who did not attend a research consultation. For students who attended a consultation, the questionnaires focused on student perceptions of what they learned during the research consultation and student preferences for the consultation service. For students who did not attend a consultation, the questionnaire focused on how the student found information for the paper. We received 57 responses in fall 2017, 68 responses in spring 2018, 95 responses in fall 2018, and 85 responses in fall 2019. The student responses illustrated the library resources and services that students remember at the end of the semester, what students felt was most beneficial about the consultation, and student preferences for future research consultations. Our data collection allowed us to compare student responses between semesters. The information gathered each semester was used to modify the research consultation the next semester. Our goal is to assess the research consultation instruction every two to three years to determine if we are meeting students' needs.
\end{abstract}

Introduction

Assessment is an important component in determining teaching effectiveness. It should be done on a regular basis to allow instructors to determine if their teaching has been effective and make changes. This paper describes the assessment of an engineering undergraduate, writing intensive class. The course, MMET 301, is in the Engineering Technology Department at Texas A\&M University in College Station, TX. It is required of all undergraduate students in the major. The same professor has taught the course since 2006. The subject librarian for the department began working with the class in fall 2009 and gave a library presentation to classes and consultations to the teams. In 2017, the subject librarian began collaborating with one of the education librarians to assess the effectiveness of the library consultations. Four assessment tools were developed and used by the librarians involved with teaching student teams. This paper discusses the end of semester questionnaire, which was the preferred assessment tool of the librarians. We conducted the detailed data analysis described in this paper after the completion of the original assessment project. This paper can contribute to a librarian's assessment toolkit and interactions with students during consultations.

Context 
The course project, which is also the department's junior capstone, is a 16 to 22 page research project on a mechanical power transmission topic that students work on in teams. This writing project requires engineering rich technical information. The students come to the course with a consumer mentality. The goal of the project is to push the students toward the industrial mindset that enables them to use and comprehend a higher level of engineering detail. There is not a specific formula for the resource quantity or source material, but the students are encouraged to use patents, engineering design specifications of product drawings, government regulatory information and manufacturing or industrial sources that provide information on engineering design, performance, life cycle and sometimes cost.

To select a project topic, students are encouraged to view the syllabus [1] and textbooks as well as talk with the course instructors. Then, search using the library resources to help narrow down their topic of interest. Successful groups have also used the marketplace to find either manufacturers or distributors that provide highly engineered industrial products to the marketplace. The company's technical literature can also help with the selection of a final topic to develop.

The writing project also contributes to students' ability to work in teams. The course instructor describes his motivation for teaching and providing experiential learning in the following way. Team and project learning in engineering help students realize the dynamics of the engineering marketplace. The knowledge gained by working in team-based education helps prepare young professionals for careers in engineering. Engineering projects rely on well educated and experienced professionals that have specific knowledge that allows them to pool their talents and experiences to accomplish complex tasks, safely and hopefully economically. The dynamic of working with individuals that the student does not get to choose and has no authority to control and of navigating the many circles of influence to accomplish a difficult task is a very useful experience and prepares them for their careers.

The course instructor has five progress reports in which he guides the student teams to complete the project in stages. If the teams follow the professor's timeline, the project is completed in 12 weeks. The library consultations are available from week 4 to week 10. Some teams come in week 4 , but most teams come in during weeks 7 to 9 . They can have two library consultations.

The librarian designed the team consultations to use the Association of College and Research Libraries' Framework's Authority is Constructed and Contextual [2] and Searching as Strategic Exploration [3] frames. These two frames complement the instructor's course objectives: demonstrate the understanding of Mechanical Power Transmission Technology and components and apply basic tools Mechanical Power Transmission to identify system or component problems/improve those components and systems in the industrial distribution marketplace. The students were taught how to identify appropriate sources for the technical content and how to create viable searches for each section of the project.

Literature Review 
Team learning for engineering students is the norm and required for ABET accreditation [4]. The purpose of team learning is for the students to learn how "to function effectively on a team whose members together provide leadership, create a collaborative and inclusive environment, establish goals, plan tasks, and meet objectives" [4]. The university's library also plays an important component in supporting the engineering programs by providing resources and collaborative study spaces. Another essential function of the library is to provide information literacy instruction [5].

The benefits of research consultations have been demonstrated by analyzing student work [6], student perceptions (e.g., Butler and Byrd [7] and Watts and Mahfood [8]), and student grades [9]. Students who attended research consultations found them useful [7], had increased confidence in finding information [8], [10], improved their searching strategies [10], and were more aware of library resources and services [8]. Compared to students in the same course who did not attend a research consultation, students who attended a research consultation were more likely to have an A course grade [9]. Together these studies demonstrate that students perceive the research consultation as beneficial and that students benefit academically from participating in a research consultation.

While the research consultation service is ubiquitous in libraries, the benefits of research consultations depend on the context. In settings in which both a research consultation and a library instruction session were required, the quality of freshman students' papers declined [11] and no improvement was found in student information literacy [12]. When the only librarian instructional interaction was a consultation, students who had a one-on-one research consultation with a librarian showed improvement in the "overall quality of sources, relevance, dates, and scope" of their papers [6]. This shows that it is important to assess the consultations in one's context in order to fully understand the benefits.

Research Purpose and Methods

\section{Data Collection}

At the end of the semester after the project had been submitted, questionnaires were used to determine if the learning outcomes of the consultation were met and to solicit feedback about the logistics of the consultation from students. We distributed hardcopy questionnaires to students on the last class day for four semesters (fall 2017, spring 2018, fall 2018, fall 2019). Different versions of the questionnaires were given to students who had a consultation with a librarian and to students who did not personally meet with a librarian for the consultation. Students self-identified to indicate which questionnaire they should receive. The questionnaire took less than 10 minutes for students to complete. Participation was voluntary and responses were anonymous. All students whether or not they answered the questionnaire were offered breakfast snacks as an incentive for participation.

The questions were different for the met with a librarian group and the did not meet with a librarian group. The questions for students who met with a librarian focused on what students 
remembered from their consultation and preferences for consultation itself. The questions for students who did not meet with a librarian focused on how students found information. Overall, the questions fit into six categories: learning outcomes, logistics, choosing a topic, finding information, citations, and satisfaction with the consultation. Some questions were retained for multiple semesters, while other questions were modified to gather more detailed information about the types of resources and search processes used by students. The majority of the questions were open-ended with students providing their own response. Only in fall 2019 did some questions contain options for students to circle. Table I shows the questions, the semester asked, and the questionnaire version.

TABLE I

Questions From Questionnaires

\begin{tabular}{|l|c|c|c|c|c|c|c|c|c|}
\hline Questionnaire Version & \multicolumn{5}{|c|}{ Met w/Librarian } & \multicolumn{3}{c|}{ Did not meet w/Librarian } \\
\hline Semester on Questionnaire & Fa17 & Sp18 & Fa18 & Fa19 & Fa17 & Sp18 & Fa18 & Fa19 \\
\hline Learning Outcomes & \multicolumn{3}{|c|}{} & & & & & & \\
\hline $\begin{array}{l}\text { What was the most } \\
\text { important thing you } \\
\text { learned during the } \\
\text { consultation? }\end{array}$ & $\mathrm{x}$ & $\mathrm{x}$ & $\mathrm{x}$ & $\mathrm{x}$ & & & & & \\
\hline $\begin{array}{l}\text { What did you learn about } \\
\text { library resources that you } \\
\text { could use in your future } \\
\text { courses? }\end{array}$ & & $\mathrm{x}$ & $\mathrm{x}$ & & & & & \\
\hline $\begin{array}{l}\text { Do you wish you had met } \\
\text { with an engineering } \\
\text { librarian before this class? } \\
\text { If so, in which course or } \\
\text { context? }\end{array}$ & & & $\mathrm{x}$ & & & & & & \\
\hline
\end{tabular}




\begin{tabular}{|c|c|c|c|c|c|c|}
\hline $\begin{array}{l}\text { If someone from your team } \\
\text { met with a librarian, what } \\
\text { did they share with you } \\
\text { about finding information } \\
\text { for your team's project? }\end{array}$ & & & & $\mathrm{x}$ & $\mathrm{x}$ & $\mathrm{x}$ \\
\hline \multicolumn{7}{|l|}{ Logistics } \\
\hline $\begin{array}{l}\text { What aspects of the one-on- } \\
\text { one team meeting were } \\
\text { most beneficial to you? }\end{array}$ & $\mathrm{x}$ & $\mathrm{x}$ & $\mathrm{x}$ & & & \\
\hline $\begin{array}{l}\text { What are your impressions } \\
\text { about the } 30 \text {-minute length } \\
\text { of the consultation? }\end{array}$ & & $\mathrm{x}$ & & & & \\
\hline $\begin{array}{l}\text { Would you be willing to } \\
\text { have your library session } \\
\text { via Zoom (web } \\
\text { conferencing) in place of } \\
\text { in-person at the library? }\end{array}$ & & & $\mathrm{x}$ & & & \\
\hline \multicolumn{7}{|l|}{ Choosing a Topic } \\
\hline $\begin{array}{l}\text { How did your team choose } \\
\text { a topic? }\end{array}$ & & & & $\mathrm{x}$ & $\mathrm{x}$ & \\
\hline $\begin{array}{l}\text { How did your team decide } \\
\text { which three topics to } \\
\text { submit for Progress Report } \\
2 ?\end{array}$ & & & $\mathrm{x}$ & & & $\mathrm{x}$ \\
\hline $\begin{array}{l}\text { What steps did you take to } \\
\text { develop your topic? }\end{array}$ & & & $\mathrm{x}$ & & & $\mathrm{x}$ \\
\hline
\end{tabular}




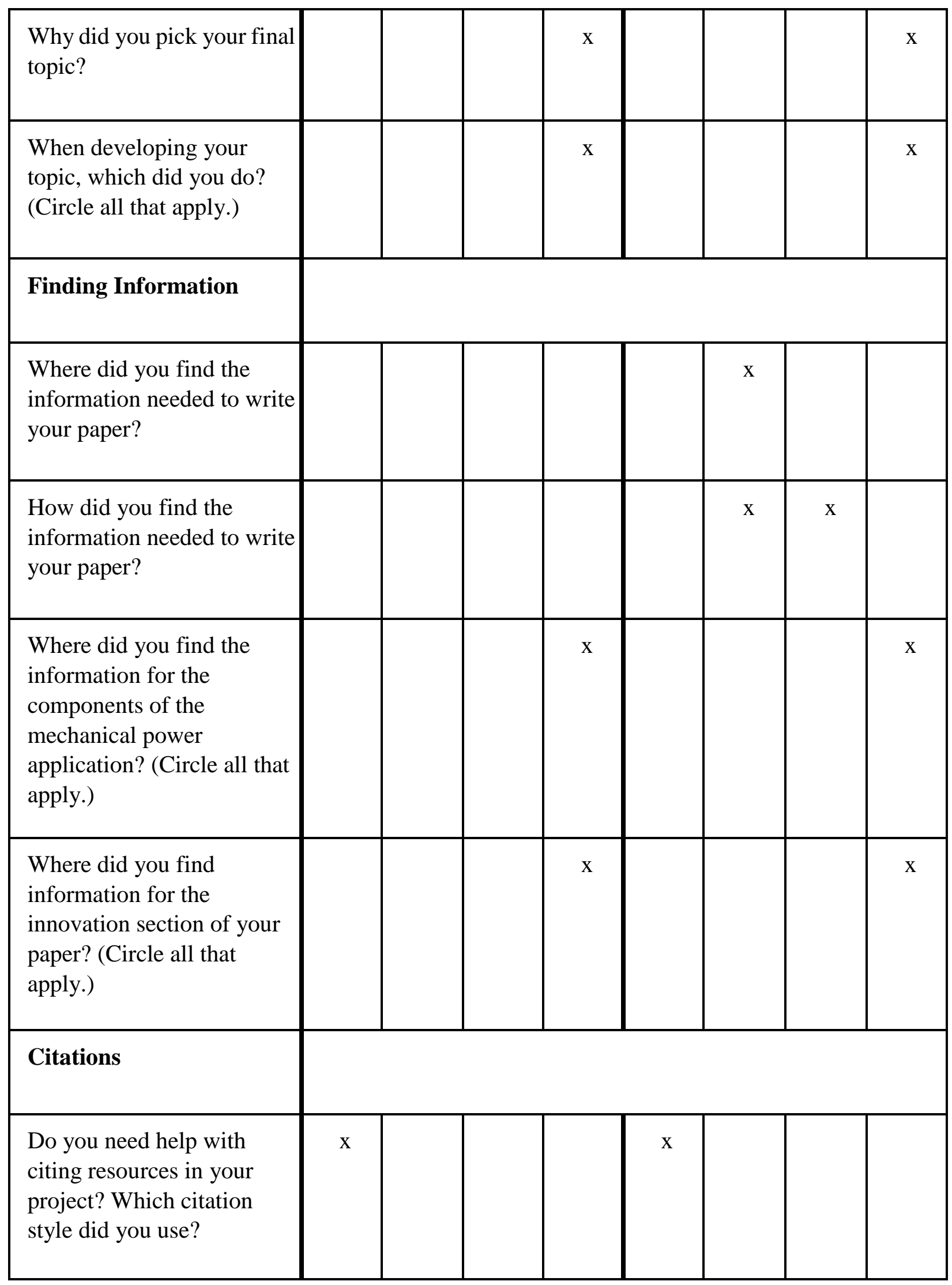




\begin{tabular}{|l|c|c|c|c|c|c|c|c|}
\hline $\begin{array}{l}\text { How many items did you } \\
\text { list in your Works } \\
\text { Cited/References? }\end{array}$ & & & & $\mathrm{x}$ & & & & $\mathrm{x}$ \\
\hline $\begin{array}{l}\text { What types of information } \\
\text { did you list in your Works } \\
\text { Cited/References? }\end{array}$ & & & & $\mathrm{x}$ & & & & $\mathrm{x}$ \\
\hline $\begin{array}{l}\text { Satisfaction with } \\
\text { Consultation }\end{array}$ & & & & & & & \\
\hline $\begin{array}{l}\text { Do you intend to schedule } \\
\text { an appointment with a } \\
\text { librarian in MMET 401? } \\
\text { Why? }\end{array}$ & & $\mathrm{x}$ & $\mathrm{x}$ & & & & $\mathrm{x}$ & \\
\hline
\end{tabular}

\section{Participants}

All students currently enrolled in MMET 301 were eligible to complete a questionnaire, but not all students enrolled in the course attended class on the last day. We received 57 questionnaires in fall 2017, 68 questionnaires in spring 2018, 95 questionnaires in fall 2018, and 85 questionnaires in fall 2019. Table II shows the breakdown of questionnaires by whether or not they met with a librarian. Students who did not meet with a librarian were asked to indicate if one of their other team members met with a librarian. The questionnaire did not have to be complete in order to be included in the data analysis; any questions that had responses were included in the data analysis.

Table II

Number of Questionnaires by Semester.

\begin{tabular}{|r|c|c|c|c|}
\hline & Fall 2017 & Spring 2018 & Fall 2018 & Fall 2019 \\
\hline Met with Librarian & 38 & 57 & 93 & 72 \\
\hline Did Not Meet with Librarian & 19 & 11 & 2 & 13 \\
\hline Total & 57 & 68 & 95 & 85 \\
\hline
\end{tabular}


Data Analysis

Quantitative content analysis and descriptive statistics were used to analyze the data. The responses for each question were analyzed separately. For the content analysis, we used the techniques of analyzing word counts and thematic analysis [13]. After transcribing the data, the ATLAS.ti word list function was used to count the number of times a word appeared in the student responses. ATLAS.ti and Excel were used to code themes in the responses. Multiple codes could be applied to each response. After the initial coding of all responses, codes were grouped into broader themes. The number of occurrences for each code were added up and percentages were calculated based on the total number of code occurrences in each theme, not the total number of student responses. Questions where students answered using yes/no or selected from given responses were analyzed using descriptive statistics.

Findings

First, we highlight the key findings for each of the six categories of questions. Then, the results for each question are described. Trends across the semesters are presented for questions that were asked multiple times, and comparisons between groups who met with a librarian, did not meet with a librarian, or had another team member meet with a librarian are provided when available.

\section{Learning Outcomes Questions}

The student responses show that the consultation increased students' awareness of library resources and knowledge of how to search for information. However, students rarely mentioned the exact names of resources, instead used the generic terms: resource, source, or database. Students also found the consultation helpful for developing a topic and learning about the parameters of the assignment. The awareness of library resources, knowledge of searching, and assignment requirements were shared with team members who could not meet with a librarian.

\section{What was the most important thing you learned during the consultation?}

Word counts of the student responses showed that the words "research(ing)," "database(s)," and "resource(s)" were the most prevalent words related to the consultation. Across all semesters, the word "research(ing)" appeared in data 73 times, while the word "search(es)" appeared 15 times. When describing the resources shown, students rarely mentioned a database or resource by name (see Table III).

Table III

Word Count Of Terms Used To Describe Resources

\begin{tabular}{|l|l|l|l|l|l|}
\hline $\begin{array}{l}\text { Resource } \\
\text { Names }\end{array}$ & Fall 2017 & Spring 2018 & Fall 2018 & Fall 2019 & Total \\
\hline
\end{tabular}




\begin{tabular}{|l|l|l|l|l|l|}
\hline database(s) & 7 & 19 & 21 & 20 & 67 \\
\hline resource(s) & 1 & 12 & 22 & 9 & 44 \\
\hline source(s) & 2 & 4 & 7 & 10 & 23 \\
\hline info(rmation) & 0 & 6 & 5 & 6 & 17 \\
\hline website(s) & 1 & 3 & 2 & 3 & 9 \\
\hline articles & 2 & 3 & 2 & 1 & 8 \\
\hline patents & 0 & 1 & 1 & 2 & 4 \\
\hline google & 0 & 3 & 0 & 0 & 3 \\
\hline engines & 1 & 1 & 0 & 0 & 2 \\
\hline knovel & 0 & 0 & 1 & 1 & 2 \\
\hline system & 0 & 1 & 1 & 0 & 2 \\
\hline
\end{tabular}

The majority of the responses to this question fell into three overarching themes: utilization of resources, awareness of resources, and the assignment. The utilization of resources theme consisted of comments related to how to search, navigate, or use library resources. For example, "how to conduct proper research," "how to best use the databases provided," and "how to find scholarly articles through the library database." The awareness of resources theme included mentions of the databases or how to locate the library resources without any indication of using the resources. For example, "number of resources available," "where all the resources are," and "access to a lot of paid subscriptions through the library." The assignment theme consisted of mentions of the paper topic, structure of the paper, or the professor's expectations for the assignment. For example, "direction for my topic," "format about how the project should be written," and "nature of the professor's attitude towards the project." 
Over the period of the study, the percentage of codes related to the assignment decreased (see Table IV). The most recent semester had an increase in responses dealing with the theme of using the library's resources. Mentions of resource awareness remained fairly constant across semesters.

Table IV

Percentage Of Codes In Each Theme By Semester

\begin{tabular}{|l|l|l|l|}
\hline Semester & $\begin{array}{l}\text { Utilization of } \\
\text { Resources }\end{array}$ & $\begin{array}{l}\text { Awareness of } \\
\text { Resources }\end{array}$ & Assignment \\
\hline Fall 2017 & $30 \%(8)$ & $22 \%(7)$ & $38 \%(10)$ \\
\hline Spring 2018 & $26 \%(22)$ & $33 \%(19)$ & $32 \%(21)$ \\
\hline Fall 2018 & $36 \%(40)$ & $32 \%(43)$ & $26 \%(25)$ \\
\hline Fall 2019 & $49 \%(34)$ & $26 \%(19)$ & $21 \%(13)$ \\
\hline
\end{tabular}

What did you learn about library resources that you could use in your future courses?

Awareness of resources and utilization of resources were overwhelming the two themes of responses to this question. Eighty-two percent of all responses fell into these two general categories: $53 \%$ in awareness of resources and $29 \%$ in utilization of resources. Example responses to awareness of resources included "multitude of different tools we can utilize for so many concepts" and "Knovel. ENGnetBASE are great for technical research." Examples of utilization of resources included "how to search for appropriate scholarly articles" and "how to work with the databases in an easier fashion."

Do you wish you had met with an engineering librarian before this class? If so, in which course or context?

The majority of students who answered this question said no $(65 ; 72 \%)$. The most frequent explanation for a no response was that a consultation with a librarian was not needed. Seventeen (19\%) responded yes, and two (2\%) responded maybe. Out of the yes responses, only eight potential instruction outlets were mentioned: MMET 340 class (4), Engineering U2 (1), ENGR 111/112 (1), freshman (1), and intro engineering course (1). 
If someone from your team met with a librarian, what did they share with you about finding information for your team's project?

In the three semesters that we asked this question to students who did not meet with a librarian, we received 21 responses. The top two pieces of information shared with other team members from the consultation were about the awareness and use of library resources $(9,41 \%)$ and the topic $(9,41 \%)$. Other information shared was related to the structure of the paper ( 3 ; $14 \%)$ and citations $(1 ; 5 \%)$.

\section{Logistics Questions}

The student responses showed that students appreciated the personalized nature of the consultation and would prefer to keep meeting with a librarian in-person. The ideal consultation length will depend on the needs and preferences of each team.

What aspects of the one-on-one team meeting were most beneficial to you?

Word counts for this question showed that students appreciated the personalized nature of the consultation between one team and one librarian (see Table V). The word "our" was one of the most prevalent words when analyzing the student responses. The next most prevalent words were "topic" and "specific" and its variants, specifically or specifics.

Table V

Word Counts Of Terms Describing the Consultation

\begin{tabular}{|c|c|c|c|c|}
\hline Word & $\begin{array}{c}\text { Spring } \\
\mathbf{2 0 1 8}\end{array}$ & $\begin{array}{c}\text { Fall } \\
\mathbf{2 0 1 8}\end{array}$ & Fall 2019 & Total \\
\hline our & 33 & 56 & 18 & 107 \\
\hline topic & 19 & 45 & 11 & 75 \\
\hline specific/ally/s & 19 & 36 & 7 & 62 \\
\hline help/ed/ful/ing/s & 12 & 20 & 13 & 45 \\
\hline question/s/ing & 17 & 14 & 8 & 39 \\
\hline team/s/s & 14 & 20 & 3 & 37 \\
\hline
\end{tabular}




\begin{tabular}{|c|c|c|c|c|}
\hline focus/ed & 8 & 28 & 0 & 36 \\
\hline us & 6 & 15 & 9 & 30 \\
\hline project & 7 & 14 & 5 & 26 \\
\hline research/ing & 8 & 8 & 8 & 24 \\
\hline time & 12 & 10 & 0 & 22 \\
\hline personable/al/ized & 9 & 2 & 2 & 13 \\
\hline attention & 4 & 6 & 0 & 10 \\
\hline information & 3 & 5 & 2 & 10 \\
\hline tailor/ed & 5 & 4 & 0 & 9 \\
\hline
\end{tabular}

Student responses were categorized into five themes: affective aspects of the consultation, project-related content, library-related content, logistical aspects, and negative comments (See table IV). In spring 2018 and fall 2018, the majority of the responses related to the affective aspects of the consultation, which included mentions of personalization, the ability to ask questions, conversation, and focused attention. For example, "make answers specific to our group and topic" and "it is tailored to your paper/topic, and advice your respective group needs for their project." Explanatory text in front of this question was removed in fall 2019, which might have led to the majority of the fall 2019 responses being about the project and libraryrelated content of the consultation. Examples of project-related content answers included "put my group in the right direction" and "talking through the essay and how to divide it up." Examples of library-related content included "how to use phrases to get more hits on databases" and "understand where to best find our information."

Table VI

Themes For Most Beneficial Aspects 


\begin{tabular}{|l|l|l|l|l|l|}
\hline Semester & $\begin{array}{l}\text { Affective } \\
\text { Aspects }\end{array}$ & $\begin{array}{l}\text { Project } \\
\text { Related } \\
\text { Content }\end{array}$ & $\begin{array}{l}\text { Library } \\
\text { Related } \\
\text { Content }\end{array}$ & $\begin{array}{l}\text { Logistical } \\
\text { Aspects }\end{array}$ & Negative \\
\hline Spring 2018 & $70 \%(52)$ & $22 \%(16)$ & $5 \%(4)$ & $3 \%(2)$ & 0 \\
\hline Fall 2018 & $61 \%(86)$ & $30 \%(42)$ & $5 \%(7)$ & $4 \%(6)$ & 0 \\
\hline Fall 2019 & $23 \%(17)$ & $36 \%(27)$ & $32 \%(24)$ & $5 \%(4)$ & $4 \%(3)$ \\
\hline Total & 155 & 85 & 35 & 12 & 3 \\
\hline
\end{tabular}

What are your impressions about the 30-minute length of the consultation?

The majority of students felt that the 30 -minute consultation was sufficient $(59 ; 64 \%)$ after an introduction to library resources was provided during their class session. Eleven students (12\%) felt that the 30-minute length was only sufficient in certain circumstances, like if the team was prepared. Seventeen students (18\%) thought the consultation should be longer.

Would you be willing to have your library session via Zoom (web conferencing) in place of in person at the library?

Over half (54\%) of the 71 students who responded to this question would not want to meet with a librarian via Zoom. Some students who responded "no" added additional comments describing their opinion. For example, "this is much better. Web chat loses personal touch" and "this would be confusing online." Twenty-seven (38\%) of students responded that they would be willing to meet via Zoom, and four (6\%) students answered yes, but indicated they would prefer in person.

\section{Choosing a Topic Category}

Students primarily relied on their interest, research, and group brainstorming for coming up with potential topics. While some students did mention that the librarian assisted in helping with topic development, ultimately, the availability of information for the paper and student interest played major roles in why teams chose particular topics.

How did you team choose a topic? 
In the spring 2018 and fall 2018, this question was only asked on the questionnaire for students who did not meet with a librarian. Three $(25 \%)$ of the responses mentioned that the team used the assistance of the librarian. Research was the most frequently occurring response with four mentions.

\section{How did your team decide which three topics to submit for Progress Report 2?}

The two primary reasons for choosing topics were based on interest $(18 \% ; 16)$ and brainstorming $(16 \% ; 14)$. Other methods that were mentioned more than twice included the availability of information $(13 \% ; 11)$, help from the librarian $(8 \% ; 7)$, researched $(7 \%$; 6), each team member came up with one $(6 \% ; 5)$, and prior experience $(5 \% ; 4)$. Comparing the responses across three consultation categories (met, did not meet, and someone else from team met) showed that interest and the availability of information were mentioned both by those who met with a librarian and those who had teammates who met. However, the availability of information was not mentioned in the responses of those who did not meet with a librarian.

What steps did you take to develop your topic?

Out of 78 responses, the top five steps that students used to develop their topic were researched $(32 \% ; 38)$, group discussion $(12 \% ; 14)$, availability of information $(10 \% ; 12)$, met with a librarian $(9 \% ; 10)$, and created an outline $(4 \% ; 5)$. The students who did not meet with a librarian did not mention research as one of the methods used to develop their topic.

\section{Why did you pick your final topic?}

The top two reasons for choosing a topic were the availability of information $(29 \% ; 27)$ and interest in the topic $(26 \% ; 24)$. Other reasons included the topic was easy to write about $(10 \% ; 9)$, the librarian assistance with topic development $(7 \% ; 7)$, the topic met the assignment requirements $(5 \% ; 5)$, and the topic had wide applicability $(5 \% ; 5)$. Students in each of the three consultation categories (met, did not meet, and someone else from team met) provided similar responses.

\section{When developing your topic, which did you do? (Circle all that apply.)}

Out of the 85 students who answered this question, the primary ways that students developed their topics were using a general Google search (23\%; 75), using the library consultation for topic development (19\%; 62), looking at the class syllabus (14\%; 44), and talking with the instructor $(12 \% ; 40)$. Students were able to select more than one answer. Table VII shows all student responses.

Table VII

How Students Developed Their Topic

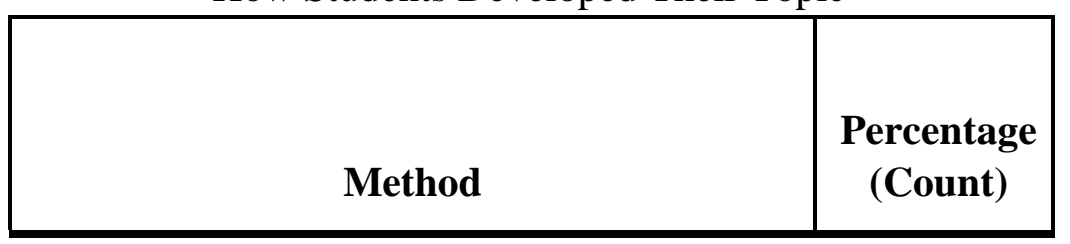




\begin{tabular}{|c|c|}
\hline General Google search & $23 \%(75)$ \\
\hline Used library session for topic development & $19 \%(62)$ \\
\hline Looked at class syllabus & $14 \%(44)$ \\
\hline Spoke with instructor & $12 \%(40)$ \\
\hline Used Wikipedia & $7 \%(23)$ \\
\hline Industry connections & $7 \%(21)$ \\
\hline Talked to friends & $5 \%(17)$ \\
\hline Used HowStuffWorks website & $4 \%(13)$ \\
\hline Databases (write in) & $3 \%(10)$ \\
\hline Talked to family & $3 \%(9)$ \\
\hline Google Scholar (write in) & $1 \%(3)$ \\
\hline
\end{tabular}

\section{Finding Information}

Overall, students reported that Google Scholar and webpages were the primary places for searching for information. The most frequently mentioned information type was a journal article, but students also reported using alternative information types like patents and product catalogs.

Where did you find the information needed to write your paper? 
When asked as an open-ended question, the 11 students who had not met with a librarian mentioned library databases $(29 \% ; 6)$, webpages $(24 \% ; 5)$, Google Scholar $(10 \% ; 2)$, Google $(10 \% ; 2)$, manuals $(10 \% ; 2)$, and articles $(10 \% ; 2)$.

How did you find the information needed to write your paper?

Across two semesters, 13 students, who did not meet with a librarian, found information from databases $(25 \% ; 6)$, websites $(13 \% ; 3)$, and online research $(8 \% ; 2)$. Some students described how they searched $(25 \% ; 6)$. Other ways of finding information, mentioned once, included an industry connection, manuals, and books. Four of the 13 responses mentioned both the type of resource they used and described how they searched that resource.

Where did you find the information for the components of the mechanical power application? (Circle all that apply.)

The 84 students who responded primarily found information from Google Scholar (16\%; $69)$, the company webpage $(15 \% ; 65)$, and journal articles $(14 \% ; 60)$. Other sources of information mentioned by at least 20 students included patents, product catalogs, Knovel, business articles, product video, book chapters, and government websites (See Table VIII).

Table VIII

Information Sources For Components And Innovation Sections

\begin{tabular}{|l|c|c|}
\hline Information Resource & $\begin{array}{c}\text { Components } \\
\text { Section }\end{array}$ & $\begin{array}{c}\text { Innovation } \\
\text { Section }\end{array}$ \\
\hline Google Scholar & $16 \%(69)$ & $20 \%(58)$ \\
\hline Company webpage & $15 \%(65)$ & $13 \%(36)$ \\
\hline Journal article & $14 \%(60)$ & $15 \%(42)$ \\
\hline Patent & $8 \%(35)$ & $9 \%(26)$ \\
\hline Product catalog & $8 \%(34)$ & $6 \%(16)$ \\
\hline Knovel & $7 \%(32)$ & $8 \%(24)$ \\
\hline
\end{tabular}




\begin{tabular}{|l|c|c|}
\hline Business article & $7 \%(31)$ & $6 \%(17)$ \\
\hline Product video & $6 \%(28)$ & $4 \%(12)$ \\
\hline Book chapter & $5 \%(22)$ & $4 \%(11)$ \\
\hline Government website & $5 \%(20)$ & $4 \%(10)$ \\
\hline Compendex & $4 \%(17)$ & $4 \%(11)$ \\
\hline Newspaper article & $2 \%(9)$ & $2 \%(6)$ \\
\hline Interview expert & $2 \%(8)$ & $1 \%(2)$ \\
\hline $\begin{array}{l}\text { Industry connection supplied } \\
\text { information }\end{array}$ & $2 \%(7)$ & $1 \%(4)$ \\
\hline Syllabus (Write in) & & $1 \%(2)$ \\
\hline
\end{tabular}

Where did you find information for the innovation section of your paper? (Circle all that apply.)

Out of the 86 students who responded to this question, six (2\%) stated that this was not their section. The top five places for information for the innovation section were Google Scholar $(20 \% ; 58)$, journal articles $(15 \% ; 42)$, company webpages $(13 \% ; 36)$, patents $(9 \% ; 26)$, and Knovel $(8 \% ; 24)$. Table VIII shows all places for information mentioned more than once.

\section{Citations Category}

MLA was the most frequently mentioned citation style. When students reported that they needed assistance with citations, they wanted help with citing nontraditional objects, like images. Students were confused by the phrase "types of information" and did not provide the responses that we expected.

Do you need help with citing resources in your project? Which citation style did you use? 
Out of 25 questionnaires, 11 students said that they needed help citing sources, and six students said that they did not need help. For those that needed help, they got help from librarians, an online citation website, and the writing center. The primary citation style used was MLA.

\section{How many items did you list in your Works Cited/References?}

The majority of students cited between 10 and 25 sources. Many of the responses given were not exact numbers, but rather ranges of numbers or shorthand like $10+$ or more than 10 .

What types of information did you list in your Works Cited/References?

In response to this question, only $43 \%$ (36) of the responses gave types of resources. Other responses provided the definition of a citation $(19 \% ; 16)$, gave the citation format used $(15 \% ; 13)$, provided generic information $(8 \% ; 7)$, listed parts of the citation $(7 \% ; 6)$, described the content of the sources $(4 \% ; 3)$, or stated they were confused by the question $(4 \% ; 3)$.

Out of the students who provided the names of resources used, articles (25) were listed most frequently, followed by websites (15) and graphics (9). Table IX lists all of the sources of information.

Table IX

Types Of Information Used In Works Cited

\begin{tabular}{|l|c|}
\hline Information Type & Count \\
\hline Articles & 25 \\
\hline Websites/Webpages & 15 \\
\hline Pictures/Diagrams/Graphics & 9 \\
\hline Journals & 7 \\
\hline Product/Company Catalogs & 7 \\
\hline Books & 6 \\
\hline Patents & 5 \\
\hline
\end{tabular}




\begin{tabular}{|l|c|}
\hline Research Papers & 5 \\
\hline Google Scholar & 2 \\
\hline Industry experts & 2 \\
\hline Manuals & 1 \\
\hline Press Releases & 1 \\
\hline Standards & 1 \\
\hline Videos & 1 \\
\hline
\end{tabular}

\section{Satisfaction with Consultation Category}

Student responses indicated that they found the consultation helpful and would meet with a librarian again.

Do you intend to schedule an appointment with a librarian in MMET 401? Why?

Out of those who met with a librarian, 89\% (133) planned to schedule an appointment next semester. As one student described, "scholastic suicide not to..." The primary reasons for intending to schedule an appointment were that the research consultation helped getting started with the project $(41 ; 27 \%)$ and was helpful $(41 ; 27 \%)$. For the help getting started with the project theme, students mentioned the consultation helped at specific points in the project. For example, "because the conversation I had with the librarian helped shape the report" and "really helped jump start the process." For the generic helpful theme, students did not expand beyond this generic description. For example, "it is both mandatory and extremely helpful" and "b/c it was very beneficial and gave us guidance." The next most prevalent specific reason was for help with their topic $(24 ; 16 \%)$. For example, "librarians are great at helping narrow down a topic to something we can reasonably write about" and "it helped focus our efforts in finding a topic." The only reasons provided for not scheduling an appointment were graduating and being comfortable with databases.

\section{Discussion}

The students' feedback was important in assessing teaching effectiveness and considering future changes on consultations. In the fall 2018 questionnaire, the subject librarian wanted to 
know if a library session was needed prior to this class. During some consultations, students said that they wished they had known about the library resources earlier. However, in the results, many of the students did not think they needed a library session prior to this class because there was no assignment that warranted it. There were a few students that recommended MMET 340 as a possible course. MMET 340 fulfills the communication requirement and has an end of semester presentation. Most students take MMET 340 before MMET 301.

Each semester, questions were added to explore new topics or dropped because there was no more information to be gleaned. Students did not comprehend all of the questions as was evident by their responses. The fall 2019 questionnaire included three questions with multiple choice answers to illicit guided answers. Similar questions from previous semesters had yielded vague, unexpected or off topic answers. However, some of the responses to the three questions were still odd. For example, in the question about which resources were used for the innovation section, Knovel was not an expected resource to be used in this section. Articles and patents were reasonable answers.

Even though the technology exists to hold the consultation virtually, many students still indicated a preference for an in-person consultation. In a 2013 study, Magi and Mardeusz [14] concluded that students valued the ability to have a conversation and interact with a librarian inperson because the face-to-face meeting was the best venue for making sure the student received the appropriate information and support. Our study found that even though video conferencing technology has improved over the past seven years and mobile technology is ubiquitous, students still valued meeting with librarians in-person.

Examining the language and terms used by students to describe the resources and information shown during the consultation provides librarians with insight about how undergraduate students view the library. First, students rarely provided the names of specific engineering resources, but rather described the way the resource was accessed (e.g., the library or Google Scholar). Additionally, when suggested answers were not provided, students did not know how to describe or to name the types of resources they used. This finding suggests that even though librarians emphasize the names of resources and the types of information each resource provides, students are more likely to remember how they accessed the resource rather than the name of the resource itself.

Second, when students mentioned "research," the context of the term often suggested that students were equating searching for literature as doing research. While literature searching is part of research, this finding indicates that librarians need to be aware that students might not realize that finding the articles is only part of the research process. The evaluation of the information, synthesis of information, and integration of the information coherently into the project are other important aspects of the research process. In addition, students often clarified research or searching with the adverbs "effectively" or "properly," which indicates the belief that there is one right way to search. Understanding the basics of building a search is important, but this finding suggests that in consultations engineering librarians should also acknowledge the cyclical nature of searching so that students see that searches can be modified as often as needed to find the best information. 
From the first semester that the subject librarian acquired the class from the previous subject librarian, team consultations were in place. The consultations were kept because they appeared to be the best way to address the diverse topics that each team was researching. The course professor and the subject librarian believed that it was critical for students to have access to the information contained in the library sources to round out the project content. The multidisciplinary nature of the topics makes understanding where and how relevant information is organized important. The survey responses seem to support that the team consultations are the best way to instruct the students. The students acknowledge the value of meeting with a librarian to learn about the resources and how to search.

\section{Limitations and Future Directions}

This study has three primary limitations. First, all of the data collected was student perceptions. Second, student responses did not always yield the information sought by the question. Third, in fall 2019, there were two instructors for the course which introduced confusion to the students and librarians as to the requirements of the project for each instructor. We did not know that the papers were graded differently, but the student feedback alerted us to the situation. For example, one professor graded only on citations not content; whereas, the other professor graded on content, technical merit, citations, etc. For future semesters, we will have to add a field in the appointment software to specify the instructor so that the librarians teach the preferred content of each professor.

Future directions include modifying the questions on the questionnaire to solicit better information from students. Unexpected changes in projects or instructors can affect librarians' teaching effectiveness and can lead to student frustration. Therefore, assessments will be timed to coincide with changes to the project in order to gauge the impact of the change on the consultation.

Conclusion

As a result of our ongoing assessment, we found that we are meeting the learning outcomes for students related to awareness of library resources and searching. We also have evidence that students see librarians as an essential resource not only for finding information, but also for developing their topic for the project. In order to assess teaching effectiveness, some type of assessment should be conducted and it should be done with regularity. Ongoing assessment will allow us to explore in more detail the types of resources students use and how they perceive the research process. 


\section{References}

[1] M. L. Golla, "MMET 301- Mechanical Power Transmission Syllabus, Spring 2020," TAMU, College Station, TX, 2020.

[2] American College \& Research Libraries, "Authority is constructed and contextual," January 11, 2016, [Online]. Available:

www.ala.org/acrl/sites/ala.org.acrl/files/content/issues/infolit/Framework_ILHE.pdf

[3] American College \& Research Libraries, "Searching as strategic exploration," January 11, 2016, [Online]. Available:

www.ala.org/acrl/sites/ala.org.acrl/files/content/issues/infolit/Framework_ILHE.pdf

[4] ABET, "Criteria for accrediting engineering programs, 2018 - 2019," [Online]. Available: https://www.abet.org/accreditation/accreditation-criteria/criteria-foraccreditingengineering-programs-2018-2019/

[5] M. Phillips, A. Van Epps, N. Johnson, and D. Zwicky, Effective engineering information literacy instruction: a systematic literature review, JAL, vol.44, no.6, 2018, https://doi.org/10.1016/j.acalib.2018.10.006.

[6] T. L. Reinsfelder, "Citation analysis as a tool to measure the impact of individual research consultations," $C \& R L$, vol.73, no.3, 2012, DOI: https://doi.org/10.5860/crl-261.

[7] K. Butler and J. Byrd, "Research consultation assessment: Perceptions of students and librarians," JAL, vol.42, no.1, 2016, https://doi.org/10.1016/j.acalib.2015.10.011_.

[8] J. Watts and S. Mahfood, "Collaborating with faculty to assess research consultations for graduate students." Behav Soc Sci Libr, 34.2, (2015), 70-87. https://doi.org/10.1080/01639269.2015.1042819.

[9] A. M. Cox and C. Neuhaus, "Complexities of demonstrating library value: An exploratory study of research consultations." PORTAL-LIBR ACAD, 19.4, (2019), 577-590. https://doi.org/10.1353/pla.2019.0036.

[10] L. Sikora, K. Fournier, and J. Rebner, "Exploring the impact of individualized research consultations using pre and post testing in an academic library: A mixed methods study," EBLIP, vol.14, no.1, 2019,_https://doi.org/10.18438/eblip29500_

[11] A. Faix, A. MacDonald, and B.Taxakis, "Research consultation effectiveness for freshman and senior undergraduate students," $R S R$, vol.42, no.1, 2014, https://doi.org/10.1108/RSR05-2013-0024_. 
[12] J. Sokoloff, and R. Simmons, "Evaluating citation analysis as a measurement of business librarian consultation impact," J Bus Finance Librariansh, vol.20, no.3, 2015, https://doi.org/10.1080/08963568.2015.1046783.

[13] R. Franzosi, "Content analysis," In The SAGE Encyclopedia of Social Science Research Methods, M. S. Lewis-Beck, A. Bryman, and T. F. Liao, Editors, Thousand Oaks, CA, USA: Sage, 2004, pp. 187-189. [Online]. Available:

https://doi.org/10.4135/9781412950589.n166

[14] T. Magi, and P. E. Mardeusz, "Why some students continue to value individual, face-to-face research consultations in a technology-rich world." $C \& R L$, vol.74, no. 6, Nov. 2013, https://doi.org/10.5860/crl12-363. 